\title{
Circulating antibodies to wheat gliadin fractions in coeliac disease
}

\author{
H. J. CORNELL \\ From the Department of Gastroenterology, Royal Children's Hospital, Melbourne, Australia
}

\begin{abstract}
Cornell, H. J. (1974). Archives of Disease in Childhood, 49, $454 . \quad$ Circulating antibodies to wheat gliadin fractions in coeliac disease. Titres of circulating antibodies to wheat gliadin fractions have been determined in children with active coeliac disease using a passive haemagglutination technique. The highest titres against fractions from S.E. Sephadex chromatography of a peptic-tryptic-pancreatic digest of gliadin were obtained against Fraction 9.

Titres of serum antibodies in children with active coeliac disease against a peptictryptic digest of gliadin and its ultrafiltrate were significantly higher than those in children free from gastrointestinal disorders.

Titres of sera from some asymptomatic sibs of the probands were abnormally high against the peptic-tryptic gliadin digest, suggesting a minor gut abnormality in these children, despite normal duodenal mucosal histology.

Haemagglutination titres of sera from patients with active coeliac disease against the protein digests and fractions evaluated seemed to be related to the toxicity of these substances in this disease.
\end{abstract}

The harmful effects of wheat gluten, and particularly one of its major proteins, gliadin, in coeliac disease have been known for some time (van de Kamer, Weijers, and Dicke, 1953; van de Kamer and Weijers, 1955). These effects have been shown to persist after digestion of these proteins with pepsin and trypsin (Frazer et al., 1959) and on further digestion with pancreatin (Bronstein, Haeffner, and Kowlessar, 1966). However, the mechanism of pathogenesis of the mucosal lesion has not been elucidated. Investigations have normally centred around the possibility of direct toxic action of incompletely digested peptides or an immunological reaction in the gut.

The presence of antibodies to gluten (and gliadin) in the serum of patients with coeliac disease has been reported by a number of workers (Heiner et al., 1962; Alarcón-Segovia et al., 1964; Taylor, Truelove, and Wright, 1964; Kenrick and Walker-Smith, 1970; Ferguson and Carswell, 1972). Altered serum immunoglobulin levels have also been reported (Immonen, 1967; Hobbs and Hepner, 1968; Hobbs et al., 1969; Kenrick and WalkerSmith, 1970), but these often returned to normal when patients were placed on a gluten-free diet.

Received 1 November 1973.
The results of Frazer et al. (1963) raised the possibility of the haemagglutinating activities of gluten preparations being related to the observed toxicity of these materials in patients with coeliac disease. However, they did not test ultrafiltrates of gluten digests. Likewise, titres against ultrafiltrates of gliadin, shown to be toxic (Krainick, Mohn, and Fischer, 1959; Bronstein et al., 1966), have not yet been reported.

Cornell and Townley (1973) have shown that Fraction 9, a chromatographic fraction of a peptictryptic-pancreatic digest of gliadin, is incompletely digested by duodenal mucosa from coeliac children in remission. This finding prompted the determination of antibodies to Fraction 9 and other fractions and digests of dietary proteins in the sera of children with active coeliac disease. In addition, antibodies to gliadin digests in sera from asymptomatic sibs of the coeliac children and from control children were determined.

Intestinal biopsy, which is the most sensitive criterion of coeliac disease (Townley and Barnes, 1973) and may show the characteristic lesion in asymptomatic subjects, was chosen to provide the most precise differentiation between affected and unaffected sibs. 


\section{Methods and materials}

Patients. Serum specimens were obtained from children with coeliac disease on a normal diet (23), from their asymptomatic sibs (25), and from children attending hospital for reasons other than gastrointestinal disorders (31). The latter group was referred to as 'normals'. The ages of the children ranged from 4 months to 12 years and were approximately matched for the 3 groups.

Diagnosis of coeliac disease was made on the basis of characteristic clinical features, histology of duodenal biopsies (Townley and Barnes, 1973), and favourable response to a gluten-free diet. The sibs had been subjected to intestinal biopsy as part of a family study to determine the incidence of the histological lesion of coeliac disease in first-degree relatives of children with this disorder.

Sera for the sib group were obtained from subjects with no clinical features of coeliac disease and who had normal duodenal mucosal histology. (Some asymptomatic sibs in the family study were shown to have the characteristic lesion of coeliac disease using standard histological methods, but these subjects were not included in the present study.) The informed consent of both parents of every child was obtained before taking a biopsy.

Antigens. The following antigens were tested.

(1) Peptic-tryptic (PT) digest of gliadin. Gliadin was prepared from commercial wheat gluten using a modified Jones procedure (Jones, Taylor, and Senti, 1959; Jones et al., 1961). Digestion of the gliadin was carried out with pepsin (Sigma 1:60,000) $0.6 \%$ on substrate, for 2 hours at $37{ }^{\circ} \mathrm{C}$ and $p \mathrm{H} 2 \cdot 3(\mathrm{HCl})$, then with trypsin (Sigma type III, $0 \cdot 6 \%$ ) for 4 hours at $p \mathrm{H} 8 \cdot 0-8 \cdot 5$ in the presence of $\mathrm{CaCl}_{2}(0.02 \mathrm{~mol} / \mathrm{l}$.) and at a concentration of $100 \mathrm{mg}$ protein $/ \mathrm{ml}$. The digest was diluted to give a concentration of approximately $50 \mathrm{mg} / \mathrm{ml}$, adjusted to $p \mathrm{H}$ $3 \cdot 1$, centrifuged at $2000 \times g$ for 15 minutes, and the $p H$ readjusted to 7 .

(2) Peptic digest of gliadin. Digestion of gliadin was carried out with pepsin as above for 15 minutes, followed by neutralization.

(3) An ultrafiltrate of PT digest of gliadin was prepared by filtering the digest prepared in (1) through a Diaflo filter (Amicon Corp., Lexington, Ky., U.S.A.) fitted with a U.M. 2 membrane (molecular weight cut-off $>1000$ ).

(4) Peptic-tryptic-pancreatic (PTC) digest of gliadin was prepared as in (1) but digesting with Cotazym (Organon Inc., New Jersey, U.S.A.), $2 \%$ on substrate, for a further 3 hours after the trypsin treatment.

(5) Fractions of the PTC gliadin digest were prepared as described by Cornell and Townley (1973).

(6) Partially deamidated PT and PTC digests were prepared by heating in a 300 -fold excess of $0.2 \mathrm{~mol} / 1$. $\mathrm{HCl}$ at $100{ }^{\circ} \mathrm{C}$ for 20 minutes. This treatment achieved $40-50 \%$ deamijation. The products were then neutralized.

(7) PT digests of zein (Corn Products Inc., Argo, Ill., U.S.A.) and lactalbumin (Nutritional Biochemicals
Corp., Cleveland, Ohio, U.S.A.) were prepared similarly to the PT digest of gliadin.

Haemagglutination method. Haemagglutination titres were determined using a modified Boyden (1951) method. Briefly, $0.3 \%$ peptide solutions (1 vol) were allowed to react with $0.5 \%$ tanned sheep erythrocyte suspension ( $5 \mathrm{vol}$ ) in phosphate buffered saline, $p \mathrm{H} 6 \cdot 4$, for 1 hour at room temperature. Concentrations of certain of the antigens remaining were determined by the Kjeldahl nitrogen method. The coated cells were then added to the human serum serially diluted in inactivated normal rabbit serum. After thorough agitation the tubes were allowed to stand overnight at $4{ }^{\circ} \mathrm{C}$. Blanks were also prepared using saline in place of serum. All assays on sera from the three groups of subjects were run on the same day with the same batch of antigen-coated tanned erythrocytes. Likewise, evaluation of the various antigens was based on assays performed on that particular day.

Immunoprecipitation tests. Sera were tested against gliadin digests and fractions using microdouble immunodiffusion (Ouchterlony, 1962).

Statistical methods. Titres of sera from different groups of individuals against PT gliadin digest and its ultrafiltrate were analysed by Students ' $t$ ' test using a $\log _{2}$ transformation, and also by Fisher's (1941) exact probability which does not assume any particular distribution of the data. Single tail tests were carried out. Groups of titres against one fraction or digest and another were compared by a paired ' $t$ ' test. Two-tail tests were used in this case.

\section{Results}

Haemagglutination titres of sera from children with coeliac disease and their asymptomatic sibs against digests of gliadin and other dietary proteins.

PT gliadin digest. The titres obtained are shown in Table I which also includes results on 31 normals for comparison. On the basis of the ' $t$ ' test, titres of coeliacs were significantly higher than those of normals $(P<0 \cdot 001)$. Fisher's exact test, based arbitrarily on titres of 640 and over, also gave $\mathbf{P}<0.001$. Titres of the sibs were significantly greater than normals $(P<0.025)$ using the ' $t$ ' test, and Fisher's exact test using the same cut-off as above gave $\mathrm{P}<0 \cdot 05$.

Ultrafiltrate of PT digest of gliadin. Titres of sera from the same patients, sibs, and normals against the ultrafiltrate of the PT gliadin digest are shown in Table II. These show a similar pattern to those of the parent digest but with generally lower titres. Again, there was a highly significant difference $(P<0.001)$ between titres of coeliacs and normals 
TABLE I

Haemagglutination titres of sera from coeliac patients and their sibs in comparison with normals

\begin{tabular}{|c|c|c|c|}
\hline Data & $\begin{array}{c}\text { Coeliacs } \\
(\text { no. }=23)\end{array}$ & $\begin{array}{c}\text { Sibs } \\
(\text { no. }=25)\end{array}$ & $\begin{array}{l}\text { Normals } \\
(\text { no. }=31)\end{array}$ \\
\hline Titre* & No. & No. & No. \\
\hline $\begin{array}{c}10 \\
20 \\
40 \\
80 \\
160 \\
320 \\
640 \\
1280 \\
2560 \\
5120 \\
10240 \\
\text { Mean titre } \\
\text { (geometric) }\end{array}$ & $\begin{array}{l}0 \\
3 \\
4 \\
2 \\
0 \\
4 \\
3 \\
3 \\
2 \\
1 \\
1 \\
\\
285\end{array}$ & $\begin{array}{l}0 \\
2 \\
8 \\
3 \\
3 \\
3 \\
3 \\
0 \\
2 \\
0 \\
1 \\
\\
151\end{array}$ & $\begin{array}{r}3 \\
2 \\
10 \\
7 \\
7 \\
1 \\
1\end{array}$ \\
\hline
\end{tabular}

Note: Antigen is peptic-tryptic gliadin digest.

$\star$ Titres here and elsewhere are shown as dilutions of sera at which tubes are still positive.

TABLE II

Haemagglutination titres of sera from coeliac patients and their sibs in comparison with normals

\begin{tabular}{c|c|c|c}
\hline Data & $\begin{array}{c}\text { Coeliacs } \\
(\text { no. = 23) }\end{array}$ & $\begin{array}{c}\text { Sibs } \\
(\text { no. = 25) }\end{array}$ & $\begin{array}{c}\text { Normals } \\
(\text { no. = 31) }\end{array}$ \\
\hline Titre & No. & No. & No. \\
\hline$<10$ & 0 & 1 & 4 \\
10 & 0 & 3 & 8 \\
20 & 6 & 7 & 9 \\
40 & 3 & 6 & 5 \\
80 & 6 & 6 & 4 \\
160 & 6 & 2 & 1 \\
320 & 2 & 0 & 0 \\
Mean titre & 69 & 34 & 20 \\
(geometric) & 6 & & \\
\hline
\end{tabular}

Note: Antigen is ultrafiltrate (molecular weight $<1000$ ) of peptic-tryptic gliadin digest.

using the ' $t$ ' test, and Fisher's exact test also gave $P<0.001$ based arbitrarily on titres of 80 and over. There was again a significant difference between the means of the sibs and normals $(P<0.025)$, but the result of Fisher's exact test was $P>0 \cdot 1$, using the same cut-off.

$P T$ digests of gliadin, zein, and lactalbumin. The results of haemagglutination tests using these digests are shown in Table III. Titres of sera from coeliacs and normals against PT gliadin digest were consistently higher $(P<0.001$ for coeliacs) than those against PT zein and lactalbumin digests.

Partially deamidated gliadin digests. The results of haemagglutination tests using partially
TABLE III

Haemagglutination titres of sera from coeliac patients in comparison with normals

\begin{tabular}{|c|c|c|c|c|}
\hline Group & $\begin{array}{l}\text { No. in } \\
\text { group }\end{array}$ & Antigen & $\begin{array}{l}\text { Mean titre } \\
\text { (geometric) }\end{array}$ & $\begin{array}{c}\text { Result of } \\
\text { paired ' } t \text { ' } \\
\text { test }\end{array}$ \\
\hline Coeliacs & 8 & $\begin{array}{l}\text { PT zein digest } \\
\text { PT gliadin } \\
\text { digest } \\
\text { PT lactalbumin } \\
\text { digest }\end{array}$ & $\left.\begin{array}{c}15 \\
380\end{array}\right\}$ & $\begin{array}{l}P<0.001 \\
P<0.001\end{array}$ \\
\hline Normals & 8 & $\begin{array}{l}\text { PT zein digest } \\
\text { PT gliadin } \\
\text { digest } \\
\text { PT lactalbumin } \\
\text { digest }\end{array}$ & $\left.\begin{array}{l}11 \\
40\end{array}\right\}$ & $\begin{array}{l}\mathrm{P}<0.001 \\
\mathrm{P}<0.01\end{array}$ \\
\hline
\end{tabular}

Note: Antigens are peptic-tryptic gliadin digest, peptic-tryptic zein digest, and peptic-tryptic lactalbumin digest.

deamidated PT and PTC gliadin digests are shown in Table IV. Even partial deamidation caused considerable reductions in titres of sera from patients with coeliac disease.

Immunoprecipitation. Lines of precipitation to PT digest were obtained with sera from only 2 children out of 18 with coeliac disease. (Sera from these 2 patients gave titres of 1280 against PT gliadin digest.) Tests on sibs and normals were all negative. Peptic digest of gliadin behaved identically.

Evaluation of fractions from S.E. Sephadex chromatography of PTC gliadin digest.

Haemagglutination. The titres obtained on sera

TABLE IV

Haemagglutination titres of sera from children with coeliac disease

\begin{tabular}{|c|c|c|c|c|}
\hline Antigen & Case no. & Titre & $\begin{array}{l}\text { Mean titre } \\
\text { (geometric) }\end{array}$ & $\begin{array}{c}\text { Result of } \\
\text { paired ' } t \text { ' } \\
\text { test }\end{array}$ \\
\hline $\begin{array}{l}\text { PT gliadin } \\
\text { digest }\end{array}$ & $\begin{array}{l}1 \\
2 \\
3\end{array}$ & $\begin{array}{r}640 \\
320 \\
1280\end{array}$ & 6407 & $P<0.01$ \\
\hline $\begin{array}{l}\text { Deamidated } \\
\text { PT gliadin } \\
\text { digest }\end{array}$ & $\begin{array}{l}1 \\
2 \\
3\end{array}$ & $\begin{array}{r}<10 \\
10 \\
20\end{array}$ & 10 & \\
\hline $\begin{array}{l}\text { PTC gliadin } \\
\text { digest }\end{array}$ & $\begin{array}{l}1 \\
2 \\
3\end{array}$ & $\begin{array}{r}80 \\
80 \\
160\end{array}$ & 100 & $P<0.01$ \\
\hline $\begin{array}{l}\text { Deamidated } \\
\text { PTC gliadin } \\
\text { digest }\end{array}$ & $\begin{array}{l}1 \\
2 \\
3\end{array}$ & $\begin{array}{l}20 \\
10 \\
20\end{array}$ & 16 & $5<0.01$ \\
\hline
\end{tabular}

Note: Antigens are peptic-tryptic gliadin digest, peptic-trypticpancreatic gliadin digest, and the deamidated products of each. 
from 6 children with coeliac disease against these fractions are shown in the Fig. The titres against Fraction 9 are significantly higher $(P<0.01)$ than those against the PTC digest using the paired ' $t$ ' test. Sera from 4 normals did not give titres $>40$ with any fraction.

Titres against Fractions 1, 2, 3, and 4 were all significantly lower $(P<0.001)$ than those against the PTC digest. Kjeldahl nitrogen determinations showed that Fractions 1, 4, 8, and 9 and the PTC gliadin digest had all absorbed onto the tanned erythrocytes to the extent of $12-15 \%$, the highest result being given by Fraction 8 .

Immunoprecipitation. Fraction 9 was the only fraction of the PTC digest to give a line of precipitation with serum from the 2 coeliac patients which were positive with peptic gliadin and PT gliadin digests.

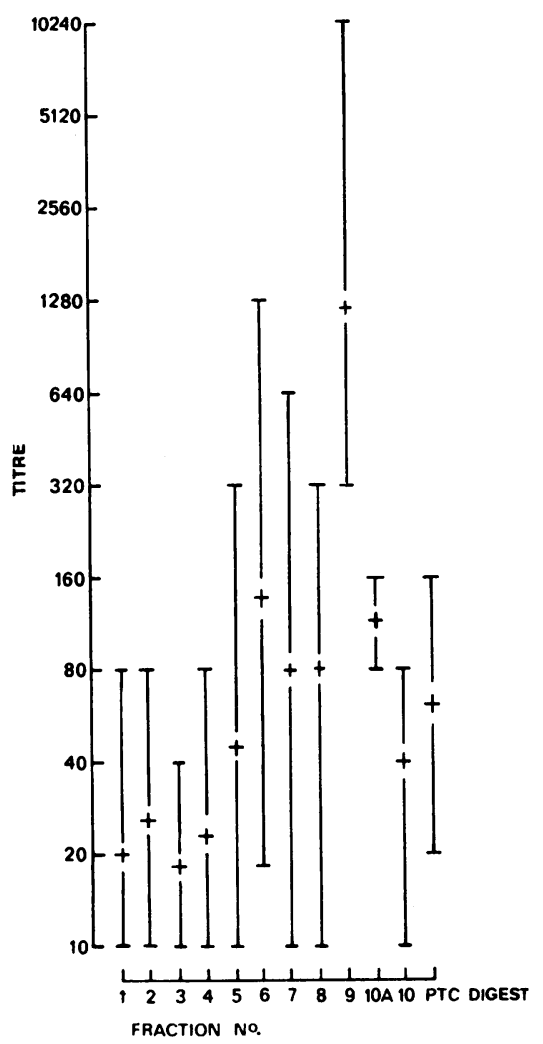

FIG.-Haemagglutination titres of coeliac sera (6 patients) against peptic-tryptic-pancreatic gliadin fractions from S.E. Sephadex. Geometric means indicated by + within ranges.
Discussion

Haemagglutination titres of sera from children with coeliac disease and their asymptomatic sibs against digests of gliadin and other dietary proteins. The results obtained with PT gliadin digest for the coeliac and normal groups were similar to those of Taylor et al. (1961), who found $62 \cdot 5 \%$ positive titres against a gluten digest in coeliac children compared with $20 \%$ in normal children. In the present study, 14 out of 23 coeliacs $(61 \%)$ and 9 out of $31(29 \%)$ normal children gave titres $>160$ against PT digest. The titres were not age dependent.

Titres of sera from patients with coeliac disease were considerably higher against PT digest of gliadin than against PT digests of zein and lactalbumin. Titres of sera from normal children against these three antigens were low, but the highest titres were obtained with PT gliadin digest. The lower titres obtained against the ultrafiltrate of the PT digest compared to titres against the parent digest may be due to differences in molecular size.

An interesting observation was that sera from some asymptomatic sibs of children with coeliac disease gave high titres against PT gliadin digest with $6 / 25(24 \%) \geqslant 640$ compared with $1 / 31(3 \%)$ of the controls. The results with the ultrafiltrate were not as striking, due to generally lower titres. Sibs with high titres may deserve follow-up for any manifestations of coeliac disease. In these subjects, a slight abnormality which results in passage of antigenic molecules across the intestinal mucosa, but which is not severe enough to produce clinical symptoms or histological changes to the mucosa, is possibly present.

Titres of sera from children with active coeliac disease against PT gliadin digest and its ultrafiltrate were quite variable from patient to patient. Factors such as the age of onset of symptoms, diet, immunological responsiveness, and severity of the mucosal damage may account for this variability.

Evaluation of fractions from chromatography of PTC gliadin digest. The high haemagglutination titres of coeliac sera against Fraction 9 and the formation of lines of precipitation with two sera against this fraction were of great interest, since this fraction has been shown to be the only one digested to a lesser extent by intestinal mucosa from coeliac children in remission than by mucosa from control subjects (Cornell and Townley, 1973). It is not likely that titres were appreciably affected by unequal coupling of antigen. When measured, the results with four fractions, including 
Fraction 9, were not greatly different to that with the PTC gliadin digest. It is, therefore, more likely that humoral antibody production is directed chiefly against incompletely digested peptides of Fraction 9 which cross the damaged mucosal epithelium.

The low haemagglutination titres obtained against fractions rich in pyrrolidone carboxylyl peptides are consistent with the findings of Sela (1969) on the importance of the $\mathrm{N}$-terminal amino group in humoral antibody production. Messer, Anderson, and Hubbard (1964) thought ring closure of $\mathrm{N}$-glutaminyl peptides could be a possible mechanism explaining the detoxification of gluten by digestion with crude papain. The low titres against partially deamidated digests parallel the observed effects of deamidation on toxicity (Weijers, van de Kamer, and Dicke, 1957), though the process used is also known to cause ring closure of $\mathrm{N}$ glutaminyl peptides.

Woodley (1972) has shown no deficiency of pyrrolidone carboxylyl peptidase in intestinal mucosa from patients with coeliac disease. Pyrrolidone carboxylyl peptides, present in PTC gliadin digest, may not be toxic to subjects with coeliac disease. In fact, preliminary evidence (Townley et al., 1973) obtained by organ culture of duodenal mucosa and by the effect of oral feeding on $\mathrm{D}(+)$ xylose excretion, supports this view. Rather, it seems that the toxicity of PTC gliadin digest is due mainly to peptides present in Fraction 9.

The results of the present work are consistent with the demonstration of incomplete digestion of Fraction 9 by coeliac duodenal mucosa, which could lead to damage by abnormally high concentrations of biologically active peptides. Enhancement of circulating antibodies as a result of the diminished integrity of the mucosal barrier may be a consequence of this process.

The author gratefully acknowledges the helpful advice given by Dr. C. S. Hosking of the Royal Children's Hospital Research Foundation. Specimens of sera used were kindly supplied by Dr. R. T. Shipman as part of a program of family studies of coeliac disease. These studies were carried out in the Royal Children's Hospital Research Foundation during tenure of the Lady Latham Research Fellowship of the Foundation.

\section{REFERENCES}

Alarcón-Segovia, D., Herskovic, T., Wakim, K. G., Green, P. A., and Scudamore, H. H. (1964). Presence of circulating antibodies to gluten and milk fractions in patients with non-tropical sprue. American fournal of Medicine, 36, 485.

Boyden, S. V. (1951). The adsorption of proteins on erythrocytes treated with tannic acid and subsequent hemagglutination by antiprotein sera. Fournal of Experimental Medicine, 93, 107.

Bronstein, H. D., Haeffner, L. J., and Kowlessar, O. D. (1966). Enzymatic digestion of gliadin: the effect of the resultant peptides in adult celiac disease. Clinica Chimica Acta, 14, 141.
Cornell, H. J., and Townley, R. R. W. (1973). Investigation of possible intestinal peptidase deficiency in coeliac disease. Clinica Chimica Acta, 43, 113.

Ferguson, A., and Carswell, F. (1972). Precipitins to dietary proteins in serum and upper intestinal secretions of coeliac children. British Medical fournal, 1, 75.

Fisher, R. A. (1941). Statistical Methods for Research Workers, 8th ed., p. 94. Oliver and Boyd, Edinburgh.

Frazer, A. C., Fletcher, R. F., Ross, C. A. C., Shaw, B., Sammons, H. G., and Schneider, R. (1959). Gluten-induced enteropathy - the effect of partially digested gluten. Lancet, 2, 252.

Frazer, A. C., Schneider, R., Morgan, D. B., and Robinson, G. B. (1963). Malabsorption syndrome: biochemical aspects. Proceedings of the Royal Society of Medicine, 56, 469.

Heiner, D. C., Lahey, M. E., Wilson, J. F., Gerrard, J. W., Shwachman, H., and Khaw, K. T. (1962). Precipitins to antigens of wheat and cows' milk in celiac disease. fournal of Pediatrics, 61, 813.

Hobbs, J. R., and Hepner, G. W. (1968). Deficiency of gamma $M$-globulin in coeliac disease. Lancet, 1, 217.

Hobbs, J. R., Hepner, G. W., Douglas, A. P., Crabbé, P. A., and Johansson, S. G. O. (1969). Immunological mystery of coeliac disease. Lancet, $1,649$.

Immonen, P. (1967). Levels of the serum immunoglobulins $\gamma \mathrm{A}, \gamma \mathrm{G}$ and $\gamma M$ in the malabsorption syndrome in children. Annales Paediatriae Fenniae, 13, 115.

Jones, R. W., Babcock, G. E., Taylor, N. W., and Senti, F. R. (1961). Molecular weights of wheat gluten fractions. Archives of Biochemistry and Biophysics, 94, 483.

Jones, R. W., Taylor, N. W., and Senti, F. R. (1959). Electrophoresis and fractionation of wheat gluten. Archives of Biochemistry and Biophysics, 84, 363.

Kenrick, K. G., and Walker-Smith, J. A. (1970). Immunoglobulins and dietary protein antibodies in childhood coeliac disease. Gut, 11, 635.

Krainick, H. G., Mohn, G., and Fischer, H. H. (1959). Weitere Untersuchungen über den schădlichen Weizenmehleffekt bei der Cöliakie. II. Die Wirkung der enzymatischen Abbauprodukte des Gliadin. Helvetica Paediatrica Acta, 14, 124.

Messer, M., Anderson, C. M., and Hubbard, L. (1964). Studies on the mechanism of destruction of the toxic action of wheat gluten in coeliac disease by crude papain. Gut, 5, 295 .

Ouchterlony, O. (1962). Diffusion-in-gel methods for immunological analysis. II. In Progress in Allergy, Vol. 6, p. 30. Ed. by P. Kallos and B. H. Waksman. Karger, Basel and New York.

Sela, M. (1969). Antigenicity: some molecular aspects. Science, 166, 1365.

Taylor, K. B., Truelove, S. C., Thomson, D. L., and Wright, R. (1961). An immunological study of coeliac disease and idiopathic steatorrhoea: serological reactions to gluten and milk proteins. British Medical fournal, 2, 1727.

Taylor, K. B., Truelove, S. C., and Wright, R. (1964). Serologic reactions to gluten and cows' milk proteins in gastrointestinal disease. Gastroenterology, 46, 99.

Townley, R. R. W., and Barnes, G. L. (1973). Intestinal biopsy in childhood. Archives of Disease in Childhood, 48, 480.

Townley, R. R. W., Bhathal, P. S., Cornell, H. J., and Mitchell, J. D. (1973). Toxicity of wheat gliadin fractions in coeliac disease. Lancet, 1, 1363.

van de Kamer, J. H., and Weiiers, H. A. (1955). Coeliac disease. V. Some experiments on the cause of the harmful effect of wheat gliadin. Acta Paediatrica, 44, 465.

van de Kamer, J. H., Weijers, H. A., and Dicke, W. K. (1953). Coeliac disease. IV. An investigation into the injurious constituents of wheat in connection with their action on patients with coeliac disease. Acta Paediatrica, 42, 223.

Weijers, H. A., van de Kamer, J. H., and Dicke, W. K. (1957). Celiac disease. Advances in Pediatrics, 9, 277.

Woodley, J. F. (1972). Pyrrolidonecarboxylyl peptidase activity in normal intestinal biopsies and those from coeliac patients. Clinica Chimica Acta, 42, 211.

Correspondence to Dr. H. J. Cornell, Institute of Child Health, The Nuffield Bldg., Birmingham B16 8ET. 